144 | Japanese Language and Literature

the broad utility of ecocriticism as an intellectual approach and to encourage authors to search for the Japanese elements of global ecocriticism theory.

Ecocriticism in Japan is not a readily accessible book. It is strongly theoretical in nature, and it is written with a highly specialized audience in mind. Beyond the strong conceptual elements, the volume offers detailed analysis of a wide-range of literature and artistic productions. The authors clearly understand Japan well and bring a great number of critical insights to the conversation. For authors outside of literacy criticism and ecocriticism, the book does an excellent job of demonstrating the challenges and benefits of evaluating an international conceptual field from a national perspective. From the outset, the editors sought to determine the Japanese contribution to a vital global field, to understand if there is an emerging subfield of Japanese ecocriticism, and to ascertain the degree to which ecocriticism elucidates the essence of Japanese cultural, values and relationship with nature. This is an ambitious agenda, one that Ecocriticism in Japan tackles with verve and real energy. While far from the final word on a topic of likely growing importance, the book is an excellent start to the conversation.

\title{
Perfumed Sleeves and Tangled Hair: Body, Woman, and Desire in Medieval Japanese Narratives
}

By Rajyashree Pandey. Honolulu: University of Hawai'i Press, 2016. xii, 209 pp. $\$ 28.00$.

\section{Reviewed by \\ Kim Mc Nelly}

What modern assumptions have we unwittingly brought into the discussion of medieval Japanese bodies and women? Rajyashree Pandey's Perfumed Sleeves and Tangled Hair: Body, Woman, and Desire in Medieval Japanese Narratives skillfully traces the relevant religious and ideological factors influencing Western discourse on the body, gender, eroticism, and agency to expose the many assumptions that underlie these modern analytical frameworks. She offers an East Asian paradigm based on Buddhist, medical, and philosophical traditions as a new basis for 
analysis. Following LaFleur in defining the Heian period as medieval on the grounds that it cannot be understood outside of a Buddhist epistemology, Pandey draws from both "high" ( $g a$ ) and "low" (zoku) literary texts, focusing the first half of her book on aristocratic bodies in The Tale of Genji, and the second half on representations of bodies and desire in setsuwa, pivoting between them with the textual figuration of Izumi Shikibu. In doing so, she shows that while the body has a diversity of textual representations across genres, the rules governing them all fall within a Buddhist paradigm. Pandey rejects a rigid divide between religion and secularism-both in medieval texts and modern society-by demonstrating how firmly ideologies are implicated in constructions of the self.

Pandey attacks an impressive number of modern assumptions relating to the stability and immutability of bodies, sex, gender, and status. Separating shintai (the modern Japanese medical-based term) from $m i$ (as used in medieval texts), she argues that bodies were not defined or limited by physical corporeal forms; clothing and hair were metonymically linked to bodies and imbued with psychological and mental attributes. The discourse of eroticism and desire are also tied to these sites of bodily manifestation.

The Introduction and chapter one describe the specific differences underlying modern conceptions of the body, gender, and biological sex in comparison with medieval Japan. Pandey draws widely from Daoist and Buddhist discourse, emaki bodily representations, Buddhist sculpture, and linguistic nuances to show a lack of separation between the mind and body in Japanese medieval representations. More than just an "anatomical entity," the body also encapsulates psychological and mental attributes (17). Correspondingly, modern discourse on the body includes aspects that do not apply to medieval texts. The 1970s feminist polarization of biological sex and gender into nature vs. nurture debates, for instance, has no place in medieval gender analysis. Pandey instead defines gender in medieval Japanese texts as "a kind of script," with the "specificity of the gendered performance... giv[ing] substance to the categories of 'male' and "female" (22). She challenges the self-evidence of the category of "women," arguing that in the feminist project to retrieve women from the hidden corners of history and texts, we have assumed these subjects would always have identified with such a category.

Pandey uses the erotic and desire as an overarching theme throughout the book but decouples eroticism from the modern liberal conception of a 
146 | Japanese Language and Literature

subjective self. Relationships in Genji unfold not from the actions of willful agents "but rather the existence of a force field of erotic and affective sensations ... which created a pleasurable ambience and generated... a propensity ... to react and respond" (2). Similarly, the modern construction of agency includes the assumption that "an autonomous individual" acts with an "innate desire to strike out against the norms of her society" (27). From this basis, action (or inaction) is categorized as resistance or complicity. Pandey suggests that we need to move beyond these assumptions based on Western thought in order to view medieval eroticism and "woman" more accurately.

Chapter two, "The Erotics of the Body in the Tale of Genji," centers the discussion of bodies around the loci of eroticism and desire, and expands the argumentative framework set forth in the introduction and chapter one with specific examples. Both Judeo-Christian associations of nudity and representations of the nude in Western art associate nakedness with the natural; this connotation does not exist in East Asian traditions, which depict bodies without clothes as also lacking social status, or "stripped of one's dignity and proper sense of self" (35). Scented with incense, attire is multi-sensory and individualized. Giving a lover a keepsake robe is likened to giving away part of one's tama (spirit), which was thought to inhabit one's garments. Along with robes, hair functioned as another visible site of an embodied being, particularly indicating an emotional and psychic state. Pandey notes that hair has particular erotic appeal during liminal situations such as "childbirth, tonsure, or death" (47).

Chapter three, "The Erotics of Power in the Tale of Genji," extends the argument from the previous chapter to address class status and firmly locate a body's performative modes within political hierarchies. Many of the specific examples here emphasize the importance of context; for instance, both gender and status together determine if casual garb produces erotic desire or signifies a lack of refinement. There are different standards and expectations for high-class aristocrats than for the female attendants who serve them. Female erotic scripts vary from "performing restraint, implacability, or vulnerability" to acting "lively, unguarded, and more responsive to male attention" (61). These variations in the performance of gender underscore the inadequacy of the category "woman." Pandey also discusses the praise or condemnation of the sexual behavior of irogonomi-"one who was fond of and receptive to amorous and erotic play" (2) — as based on social status, gender, and age. 
Chapter four, "Woman, Love, Poetry, and Enlightenment: Izumi Shikibu as Topos," pivots from the above discussion of aristocratic bodies and eroticism in Genji to Buddhist discourse and later medieval narratives about women, sexual desire, and enlightenment. It argues against biographical readings of poetic texts such as Izumi Shikibu nikki, whose use of third-person narration uses the trope of "onna" in place of Izumi, allowing a "stylized performance of waiting for the lover" (83). Pandey resists reading Izumi Shikibu as a historic figure as rehabilitated in later medieval texts, instead configuring her literary representation in setsuwa as an ideal topos through which to explore the intersections of Buddhism, erotics, and waka poetry. Thus the figure of Izumi Shikibu and women in these texts function like the semiotic codes Vyjayanthi R. Selinger describes in Authorizing the Shogunate: Ritual and Material Symbolism in the Literary Construction of Warrior Order, as "a discursive construction, a representational space within which the cultural and historical tensions ... can be negotiated" (13).

Chapter five, “"Meditating on the Impure Body': The Generic Transformations of a Medieval Topos," traces discourses surrounding fujōkan (Buddhist meditation on the impure body) within the Buddhist canon, representational imagery, and the courtly literary tradition. Discourses on the body vary by genre. Canonical Buddhist texts simultaneously show bodies of holy persons preserved in their enlightenment and posit the body as impure, a thing to be reviled. This second reading takes the female body as the most necessary to address because it was considered the most beautiful and a greater danger to celibate monks. Indian Buddhist narratives show this deconstruction of female beauty through the dissolution of corpses. There is a tension, however, between this and the discursive mode of monogatari discussed above, which shows the visible bodily ephemerality—dying, emaciated (female) bodies - effecting erotic responses. Pandey turns to two setsuwa collections, Hosshinshū (A collection of tales of religious awakening) and Kankyo no tomo (A companion in solitude), attributed to Kamo no Chōmei and Priest Keisei respectively, to demonstrate how they drew from both Buddhist doctrine and the courtly literary tradition.

In taking up treatment of the female body in Buddhist texts, Pandey enters disputed territory about whether or not Buddhism is characterized by misogynistic discrimination. Defining misogyny narrowly as "a conscious and willful hatred of women by men" (24), Pandey argues that this is not the case and tirelessly contextualizes Buddhist ideology, 
148 | Japanese Language and Literature

rejecting the anthropomorphizing of religion and showing that Buddhist discourse on women's bodies was less concerned with the hierarchical relationship between men and women than the challenges to attaining enlightenment. The multiple readings of women's bodies through various genres in this chapter destabilize the idea that Buddhism had a singular message.

The Epilogue demonstrates concrete examples of readings that Pandey argues against and suggested corrections. She rejects readings that place agency and desire exclusively in the realm of humans, such as transmuting the nonhuman into figural representations for humans with snakes as phallic, or a snake's mouth as yonic. Instead, she points to the lack of separation among the ten Buddhist realms from which we have images of hungry ghosts (gaki zosshi) inhabiting and interacting with the human realm; women who turn into foxes; and gods and buddhas disguised as humans. Rather than erasing the nonhuman, these setsuwa transmit a didactic warning about "the danger attendant on the collision of the human and nonhuman realms" (152).

Perfumed Sleeves and Tangled Hair should be read by not only anyone with an interest in premodern gender and women's studies but also all who grapple with trying to apply modern analytic categorizations onto premodern subjects. Using her combination of expertise in Buddhist and literary studies, Pandey provides a guide for a non-anachronistic discussion using analytic frames that hold meaning for us today. The wide range of evidence Pandey provides to support her readings of the main texts, from canonical Indian Buddhist texts to Japanese poetic treatises, not only shows the massive effort that went into this undertaking but also opens the scope of the project into a surprisingly wide field. Her methodical and clear progressive argument allows the reader to enjoy these supporting arcs without being overwhelmed by them.

If I am allowed to quibble, it would be to ask for even more. The discussion of social status in chapter three could have gone further to situate the varying socially-acceptable performances of female patrons and attendants within the networks of power inherent in such relationships. Pandey earlier notes how women's names privilege the status implied through interpersonal relations over womanhood, but she limits her discussion to familial relationships: mother, wife, daughter, sister (21). Female attendants at court were frequently referred to by the name of their patron, such as Kenreimon'in Ukyō no Daibu or Sōhekimon'in Shōshō no Naishi, and their role in serving a female patron including acting as her 
representative and intermediary with the world outside of her sheltering screens. In this sense, the female attendant serves as an extension of her mistress. How does this configuration of power affect how we see the attendants' gendered performance in the realm of erotic play as irogonomi? Do their actions evoke eroticism for the woman they serve? A discussion of these questions could broaden the chapter's argument to include a deconstruction of using "intersectionality" to describe the intersection of gender and class in the Heian court. Pandey never uses this term, but it would easily align with her goals in this chapter of historical re-orientation to the categories of gender and sex within hierarchical power relationships.

Overall, this book is an excellent, accessible contribution to the fields of literature and Buddhism, and a challenge to existing scholarship on literary representations of premodern Japanese women. It will interest scholars of Japanese literature, Buddhism, and gender studies. The Introduction, chapter one, and the epilogue could easily be used in an upper-level undergraduate seminar, perhaps early in the semester, to destabilize students' preconceptions and question their assumed cultural connotations of gender and the body alongside the modern worldview they bring to translated texts. Given the ongoing political debates about a fluid understanding of sex and gender in popular discourse, Pandey's book can be used as a basis for fostering discussion in a context removed from personal beliefs and stakes, thereby inclusively facilitating the introduction of these concepts.

As Japanese studies struggles against a push to redistribute funding to the sciences and technological advancement, some have offered a defense for our field's relevancy through encapsulation into world literature or global history. Pandey alternatively argues that an area studies perspective is critical for understanding medieval texts, and the questions they reflect back onto our modern analytical frameworks are a resource we should not ignore. 